\title{
Analisis Respon Mahasiswa Terhadap Semester Online pada Mata Kuliah Fisika Dasar
}

\author{
${ }^{1}$ Alpiana Hidayatulloh, ${ }^{2}$ Muh. Iman Darmawan, ${ }^{3}$ Hardani \\ ${ }^{1}$ Prodi Teknik Sipil, FSTT, Universitas Pendidikan Mandalika, Jl. Pemuda No.52, \\ Mataram,NTB \\ ${ }^{2}$ Prodi Teknik Lingkungan, Fakultas Teknik, Universitas Hamzanwadi, Jl.Cut Nyak Dien \\ No.85,Pancor, Selong, Kabupaten Lombok Timur,NTB,83611 \\ ${ }^{3}$ D3 Farmasi Politeknik Medika Farma Husada Mataram, Jl.Medika Farma No.1, Lingkungan \\ Batu Ringgit Selatan Sekarbela \\ Email Korespondensi: alpianahidayatulloh11@gmail.com
}

\begin{tabular}{|c|c|}
\hline Article Info & lbstract \\
\hline $\begin{array}{l}\text { Article History } \\
\text { Received: } 25 \text { August } 2021 \\
\text { Revised: } 21 \text { Dec } 2021 \\
\text { Published: } 30 \text { Dec } 2021\end{array}$ & \multirow{2}{*}{$\begin{array}{l}\text { This study aims to determine student responses to the implementation of online } \\
\text { semesters in basic physics courses. The subjects of this study were first } \\
\text { semester students as many as } 28 \text { students. The instrument used is a } \\
\text { questionnaire of } 5 \text { statements answered via google form. Then the answers to } \\
\text { the questionnaire were analyzed using a qualitative description, the data of } \\
\text { which was written in a table. Based on the results of data analysis, the } \\
\text { percentage of student responses to the online basic physics course semester is } \\
83 \% \text {. Based on the percentage, this shows that students give a positive } \\
\text { response to the semester of basic physics courses. }\end{array}$} \\
\hline $\begin{array}{l}\text { Keywords } \\
\text { Student Response; online } \\
\text { semester; basic physics }\end{array}$ & \\
\hline Infor & Abst \\
\hline $\begin{array}{l}\text { Seja } \\
\text { Dite } \\
\text { Dire } \\
\text { Dipu }\end{array}$ & \multirow{2}{*}{$\begin{array}{l}\text { Penelitian ini bertujuan untuk mengetahui respon mahasiswa terhadap } \\
\text { pelaksanaan semester online pada mata kuliah fisika dasar. Adapun subjek } \\
\text { penelitian ini adalah mahasiswa semeseter satu sebanyak } 28 \text { mahasiswa. } \\
\text { Instrumen yang digunakan adalah angket sebanyak } 5 \text { pernyataan yang dijawab } \\
\text { melalui google form. Kemudian jawaban angket dianalisis dengan deksriptif } \\
\text { kualitatif yang datanya dituangkan dalam sebuah tabel. Berdasarkan hasil } \\
\text { analisis data persentase hasil respon mahasiswa terhadap semester mata kuliah } \\
\text { fisika dasar secara online sebanyak } 83 \% \text {. Berdasarkan persentasinya hal ini } \\
\text { menunjukkan bahwa mahasiswa memberikan respon positif terhadap semester } \\
\text { mata kuliah fisika dasar }\end{array}$} \\
\hline $\begin{array}{l}\text { Kata kunci } \\
\text { Respon Mahasiswa; } \\
\text { semester online; fisika } \\
\text { dasar }\end{array}$ & \\
\hline
\end{tabular}

Sitasi: Hidayatulloh, A., Darmawan, M.I., \& Hardani, H. (2021), Analisis Respon Mahasiswa Terhadap Semester Online pada Mata Kuliah Fisika Dasar, Kappa Journal. 5(2), 200-206.

\section{PENDAHULUAN}

Wabah covid - 19 melanda banyak negara di dunia salah satunya indonesia, indonesia menduduki posisi 31 dari 40 negara dengan jumlah kasus terbanyak di dunia (Hennida: 2020). Berdasarkan data tersebut maka indonesia berada dalam keadaan kritis sehingga perlu solusi yang tepat untuk menghentikan penyebaran virus tersebut, dimana virus covid -19 ini merupakan salah satu virus yang penularannya sangat cepat. Salah satu kebijakan pemerintah dalam menghentikan penyebaran virus covid-19 ini adalah PSBB (Pembatasan Sosial Berskala Besar). Kebijakan tersebut memberikan dampak diberbagai aspek pemerintahan tidak terkecuali aspek pendidikan. Dengan adanya aturan untuk PSBB maka semua jenjang pendidikan tidak terkecuali perguruan tinggi diatur oleh pemerintah untuk melakukan proses 
pembelajaran secara online (daring) (Misbah et al., 2021). Sesuai dengan surat edaran Kemendikbud Dikti No.1 Tahun 2020 yang berbunyi bahwa melalui kementerian pendidikan dan kebudayaan pemerintah telah melarang perguruan tinggi untuk melaksanakan tatap muka(konvensional) dan memerintahkan untuk menyelenggarakan perkuliahan atau pembelajaran secara daring. Perguruan tinggi dituntut untuk dapat menyelenggrakan pembelajaran secara daring atau online (Firman, F \& Rahayu, S. 2020)

Pembelajaran daring (online)merupakan satu bentuk pembelajaran jarak jauh dengan bantuan internet dengan menggunakan berbagai jenis aplikasi seperti zoom, class room, WA dan lain - lain (Syahidi et al., 2020). pembelajaran daring adalah pembelajaran yang mampu mempertemukan mahasiswa dan dosen untuk melaksanakan interkasi pembelajaran dengan bantuan internet (Kuntarto E. 2017). Pada tataran pelaksanaanya pembelajaran daring memerlukan dukungan perangkatperangkat mobile seperti smarphone atau telepon adroid, laptop, komputer, tablet, dan iphone yang dapat dipergunakan untuk mengakses informasi kapan saja dan dimana saja (Gikas \& Grant, 2013).

Dengan adanya larang tatap muka maka penguatan proses pembelajaran dilakukan secara daring, sesuai dengan pendapat (Darmalaksana, 2020) Perguruan tinggi pada masa WFH perlu melaksanakan penguatan pembelajaran secara daring. Sehingga semua aktivitas pembelajaran di semua perguruan tinggi dilakukan secara daring tidak terkecuali ujian akhir semester. Begitu juga halnya dengan salah satu perguruan tinggi swasta yaitu Universitas Pendidikan Mandalika melaksanakan semua kegiatan perkuliahan mulai dari pembelajaran sampai dengan Ujian Akhir Semester(UAS) untuk semua mata kuliah dilakukan dengan daring.

Begitu juga halnya dengan ujian akhir semester pada mata kuliah fisika dasar dilaksanakan secara daring melalui aplikasi zoom dengan pengumpulan jawaban melalui email. Pelaksanaan UAS fisika dasar berjalan dengan lancar walaupun kadang memiliki kendala internet yang tidak lancar sehingga banyak mahasiswa yang telat pengumpulan jawaban. Sehingga dalam hal ini peneliti menganalisis bagaimana respon mahasiswa terhadap pelaksanaan UAS fisika dasar secara daring(online).

\section{METODE}

Penelitian ini dilakukan di Fakultas Sains,Teknik dan Terapan (FSTT) program studi teknik sipil semester satu, subjek diambil semuanya berjumlah 28 mahasiswa. Dalam penelitian ini menggunakan metode deskriptif kualitatif dan penyajian datanya dalam bentuk tabel dan teks naratif. Adapun teknik pengumpulan data dalam bentuk kuesioner dan instrumen penelitiannya berupa angket pernyataan yaitu dengan menggunakan angket google form. Angket menurut Sugiyono (2009) adalah teknik pengumpulan data yang dilakukan dengan cara memberikan seperangkat pertanyaan atau pernyataan tertulis kepada responden untuk menjawab. Sedangkan suharsimi arikunto menyatakan angket adalah daftar pertanyaan yang diberikan kepada orang lain yang bersedia memberikan respon sesuai dengan permintaan pengguna. Pada penelitian ini peneliti menyiapkan 5 pernyataan yang akan dijawab oleh responden(siswa) yang disusun dengan 4 kategori yaitu "sangat setuju", "setuju", "tidak setuju", "sangat tidak setuju". Angket yang disediakan oleh peneliti adalah angket dengan pernyataan positif. Analisi data angket menggunakan analisis kualitatif 
dimana sebelum dianalisis dengan kualitiaf terlebih dahulu dianalisis secara kuantitatif dengan perhitungan persentasi. Adapun rumus persentasi yang digunakan dalam perhitungan angket sebagai berikut:

$P=\frac{f}{N} \times 100 \%$

Keterangan

$\mathrm{P}=$ Persentase dari setiap jawaban

$\mathrm{f}=$ Frekuensi tiap jawaban dari responden

$\mathrm{N}=$ jumlah responden

Untuk menginterpretasi data hasil perhitungan dan mengambil kesimpulan tingkat persentasi mahasiswa maka ditetapkan suatu kriteria penilaian persentasi dari jawaban mahasiswa yang terdiri dari 3 kategori yaitu baik,cukup dan kurang. Menurut Tophan James dan Siotnik kenet A (dalam Wulandari, 2011:40) mengkategorikan hasil persentasi sebagai berikut:

Tabel 1. Rentang Persentasi

\begin{tabular}{lllll}
\hline No & \multicolumn{3}{l}{ Persentase } & \multicolumn{2}{l}{ Interpretasi } & \\
\hline 1 & $0, \%$ & - & Respon & tidak \\
& $49 \% \%$ & & positif & \\
\hline 2 & $50 \%$ & - & Respon & kurang \\
& $69 \%$ & \multicolumn{2}{l}{ positif } & \\
\hline 3 & $70 \%$ & - & Respon positif \\
& $84 \%$ & & & \\
\hline 4 & $85 \%$ & - & Respon & sangat \\
& $100 \%$ & & positif & \\
\hline
\end{tabular}

Khabibah, 2006 clt. Yamasari,2010

\section{HASIL DAN PEMBAHASAN}

Dari hasil pengumpulan data diperoleh data hasil pernyataan angket yang dijawab oleh mahasiswa. Angket yang dijawaba mahasiswa ada 5 penyataan yang sudah dijawab oleh mahasiswa. Adapun hasil persentasi jawaban siswa akan dideskripsikan sebagai berikut:

1. Semester online fisika dasar mengajarkan bertanggung jawab dan mandiri 


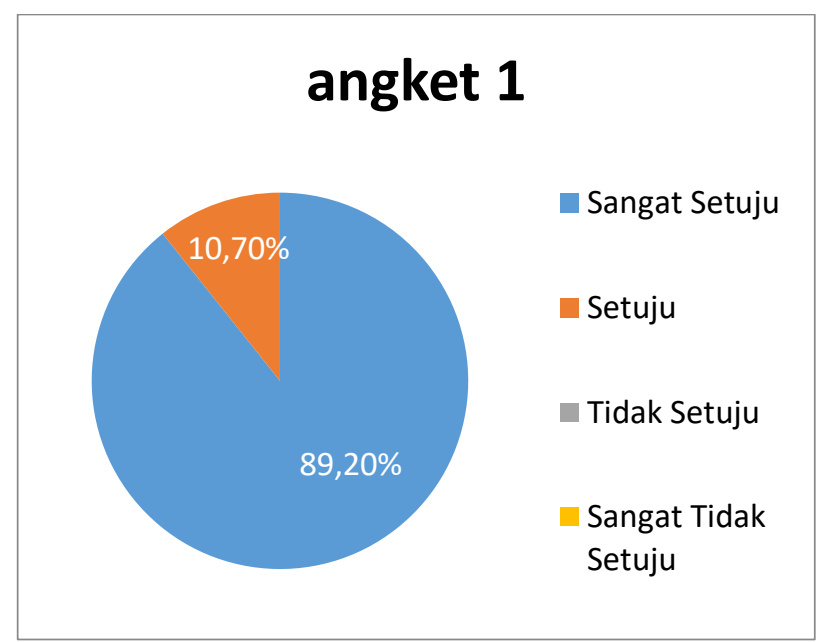

Gambar 1. Jawaban angket mahasiswa untuk pernyataan 1

Pada pernyataan pertama $89,20 \%$ mahasiswa menjawab sangat setuju bahwa semester online mengajarkan mahasiswa memiliki rasa tanggung jawab dan mandiri. Hal itu di dukung oleh Yaniawati, 2010 pembelajaran secara daring dapat melatih kemandirian peserta didik dalam mengikuti proses pembelajaran.

2. Semester online fisika dasar dilakukan seterusnya

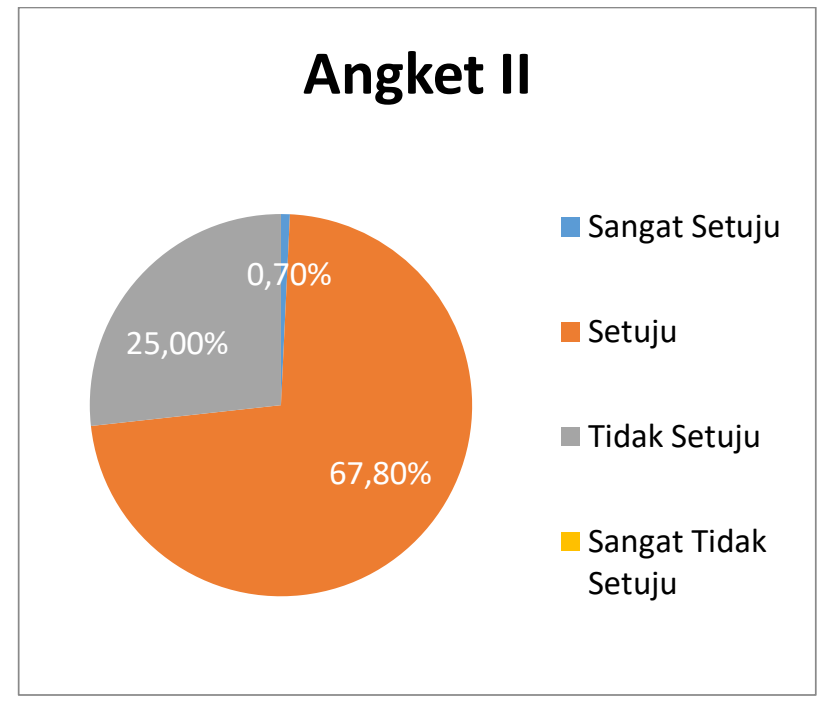

Gambar 2. Jawaban angket mahasiswa untuk pernyataan 2

Pada pernyataan kedua ini ada $0,70 \%$ mahasiswa menjawab sangat setuju dengan semester secara online waktu yang dan waktu , 25\% menjawab setuju dengan semester secara online dikarenakan waktu dan tempat yang sangat fleksibel hal ini didukung oleh (Gikas dan Grant, 2013 ) menyatakan bahwa pelaksanaan pelaksanaan pembelajaran daring membutuhkan adanya fasilitas sebagai penunjang seperti smartphone, laptop yang digunakan untuk mengakses informasi dimanapun dan kapanpun. Yang tidak setuju sebanyak 67,80\% karena jaringan internet yang sering menjadi kendala untuk melakukan daring baik itu pada saat pembelajaran ataupun semester sehingga sering mahasiswa mengalami keterlambatan untuk mengikuti daring. Karena salah salah satu elemen yang paling penting untuk berjalannya pembelajaran online adalah internet. sejalan dengan pendapat dari Isman yang mengatakan bahwa pembelajaran online merupakan proses pembelajaran yang membutuhkan internet 
3. Semester online fisika dasar lebih efektif daripada tatap muka

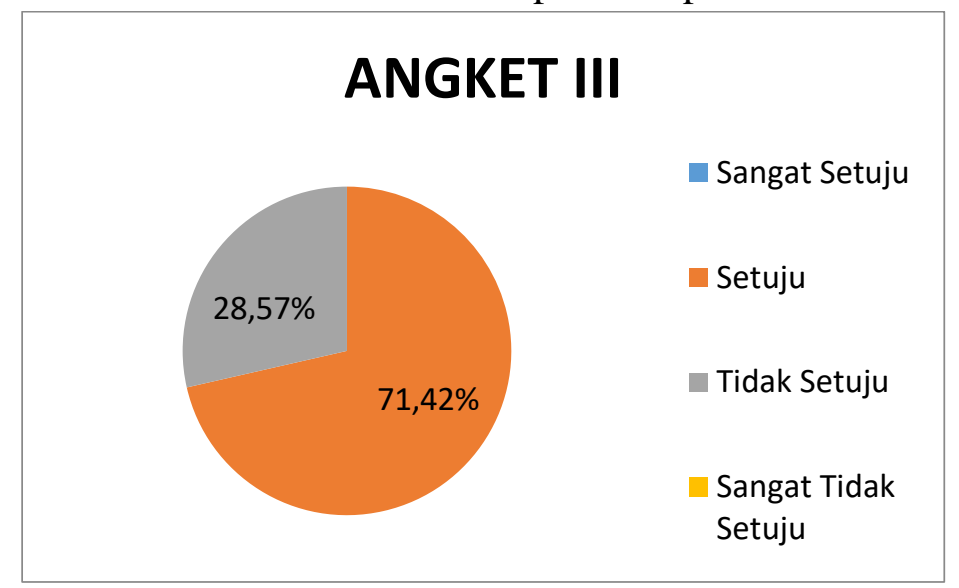

Gambar 3. Jawaban angket mahasiswa pada pernyataan 3

untuk pernyataan angket ketiga tentang keefektifan dari semester secara daring, pada pernyataan ini mahasiswa menjawab setuju 71,42\% bahwa ujian akhir semester pada mata kuliah fisika dasar efektif dilakukan secara online dan mahasiswa yang tidak setuju sebanyak $28,57 \%$.

4. Semester online fisika dasar lebih efisien daripada tatap muka

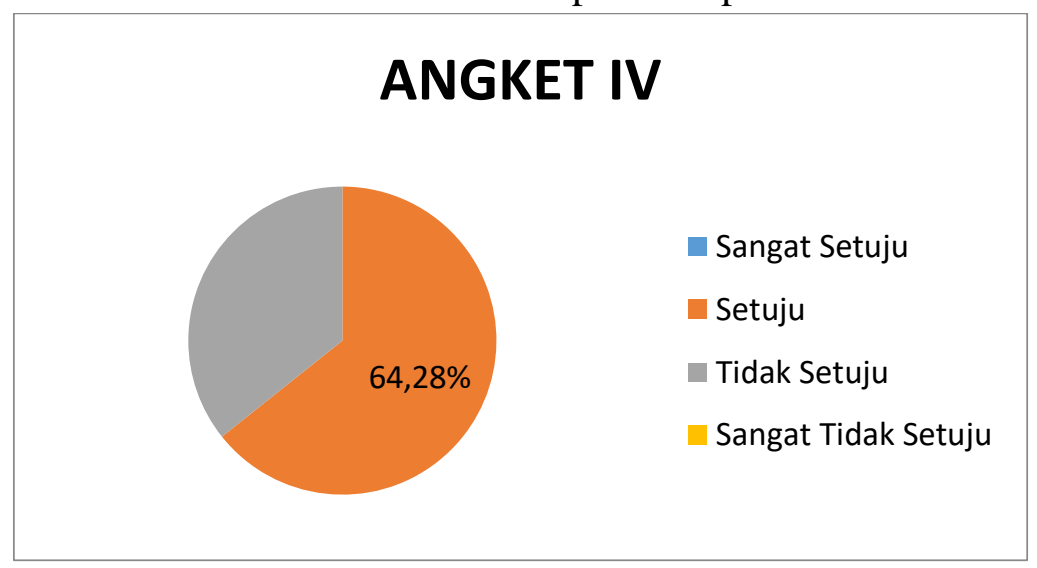

Gambar 4. Jawaban angket mahasiswa pada pernyataan 4

Pada semester online mahasiswa menjawab pertanyaan sangat setuju dan setuju. 53,60\% mahasiswa menjawab sangat setuju semester secara online lebih efisien dari tatap muka dan $46,4 \%$ menjawab setuju dengan semester secara online. Semester secara online waktu pengerjaan soal lebih lama daripada tatap muka dan bisa dikerjakan dimana saja. Hal ini didukung oleh pendapat

5. Semester online pada mata pelajaran fisika dasar mengajarkan mahasiswa untuk menghargai waktu 


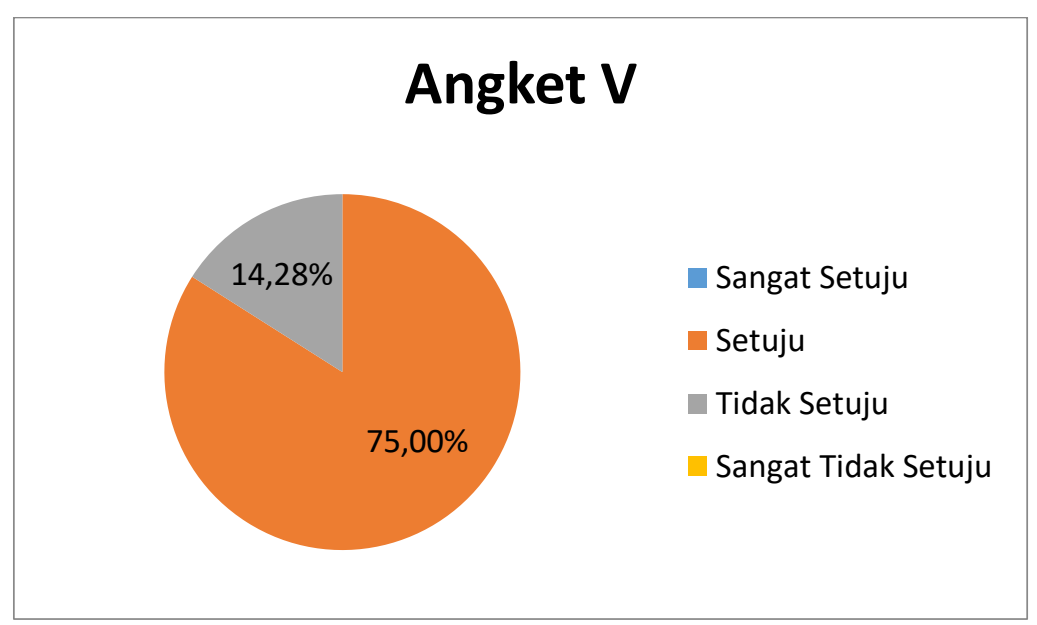

Gambar 5. Jawaban angket mahasiswa pada pernyataan 5

Pada perrnyataan kelima siswa menjawab setuju dan tidak setuju, mahasiswa yang menjawab setuju sebanyak $75 \%$ dan tidak setuju sebanyak $14,28 \%$. Mahasiswa yang menjawab setuju lebih banyak dari yang tidak setuju, hal itu disebabkan karena semua aktivitas semester dari pengerjaan soal dan pengumpulan jawaban dilakukan secara online dan durasi pengumpulan jawaban sudah ditentukan. Sehingga penting untuk mahasiswa mengerjakan dan mengumpulkan secara tepat waktu.

Adapun hasil analisis data dari angket dapat dilihat pada tabel 3 berikut ini

Tabel 3. Deskripsi respon mahasiswa terhadap semester online

\begin{tabular}{llllll}
\hline Tes & $\begin{array}{l}\text { Jumlah } \\
\text { mahasiswa }\end{array}$ & max & Min & mean & SD \\
\hline Angket & 28 & 109 & 66 & 83,3 & 13,12 \\
\hline
\end{tabular}

Dari tabel 3 dapat dilihat bahwa respon siswa terhadap pelaksanaan semester dengan online. Dilihat dari nilai rata - rata(mean) hasil respon yang mencapai $83,3 \%$ berdasarkan tabel 1 dapat dikategorikan respon mahasiswa terhadap semester dengan online memberikan respon positif karena berada pada rentang $70 \%-84 \%$.

\section{KESIMPULAN}

Adapun kesimpulan yang dapat diambil dari penelitian ini adalah sebagain besar mahasiswa memberikan respon positif terhadap pelaksanaan semester secara online(daring) pada mata kuliah fisika dasar terlihat dari hasil jawaban pernyataan angket mahasiswa dari pernyataan 1 sampai 5 datanya dapat dilihat dari gambar 1 sampai 5. Dan persentase hasil respon mahasiswa mencapai $83 \%$ yang berada pada rentang $70 \%$ - $84 \%$ yang berada pada respon positif.

\section{SARAN}

Berdasarkan hasil dan kesimpulan dari penelitian yang telah diuraikan, maka disarankan beberapa hal sebagai berikut: kepada peneliti lain untuk menggunakan media pembelajaran daring lebih efektif selain dari zoom salah satu pelaksanaan ujian akhir semester sehingga dapat berjalan dengan baik; Sebaiknya pelaksanaan ujian semester secara daring dilakukan dengan menentukan waktu pengumpulan supaya mahasiswa dapat menghargai waktu.

\section{DAFTAR PUSTAKA}


Akhmad, Nur Amaliah. 2020. Analisis Respon Mahasiswa Terhadap Perkuliahan Daring Di Prodi Biologi STKIP PI Makasar. Jurnal Pendidikan dan Terapannya. 3(2), 56 - 61

Falahudin. 2014. Pemanfaatan Media Dalam Pembelajaran. Jurnal Lingkar Widyaiswara. 1(4). $104-117$

Firman. 2020. Pembelajaran Online di Tengah Pandemi Covid -19. Indonesian Journal of Educational Science(IJES). 2(2), 81 - 89

Fitriyani, Y.,Fauzi, I \& Sari, M.Z. (2020). Motivasi Belajar Mahasiswa Pada Pembelajaran DaringSelama Pandemik Covid -19. Jurnal Kepnedidikan: Jurnal Hasil Penelitian dan Kajian Kependidikan. 6(2), 165 - 175

Mastura., Rustana,S. 2020. Dampak Pandemi Covid-19 Terhadap Proses PengajaranBagi Guru dan Siswa. Jurnal Studi Guru dan Pembelajaran. 3(2), 170 - 175

Misbah, M., Khairunnisa, Y., Amrita, P. D., Dewantara, D., Mahtari, S., Syahidi, K., Muhammad, N., Prahani, B. K., \& Deta, U. A. (2021). The effectiveness of introduction to nuclear physics e-module as a teaching material during covid-19 pandemic. Journal of Physics: Conference Series, 1760(1). https://doi.org/10.1088/17426596/1760/1/012052

Syahidi, K., Hizbi, T., Hidayanti, A., Ditinjau, B., Kemampuan, D., \& Kritis, B. (2020). The Effect of PBL Model Based Local Wisdom Towards S tudent 's Learning Achievements on Critical Thinking Skills Pengaruh Model PBL Berbasis Kearifan Lokal Terhadap Prestasi. Kasuari: Physics Education Journal ( KPEJ) Universitas Рариа, 3(1), 61-68.

Mislaini \& Panjaitan,R.G.P. 2013. Respon Siswa Terhadap Penggunaan Media Pembelajaran Oleh Guru IPA Biologi di Kecamatan Kendawang. Jurnal Wahana Bio. 9(1-2). 1 - 10

Naserly,M.K. 2020. Implementasi Zoom, Google Classroom dan Whatsap Group Dalam Mendukung Pembelajaran Daring(online) Pada Mata Kuliah Bahasa Inggris Lanjut. Akasara Public. 4(2). 60 - 64

Sadikin,Ali., Hamidah,Afreni. 2020. Pembelajaran Daring di Tengah Wabah Covid-19. Jurnal Ilmiah Pendidikan Biologi. 6(2), 214 - 224

Widayati,S., Hotimah, N., \& Rakhmawati,N.I.S. (2020). Respon Mahasiswa Pada Proses Pembelajaran Mata Kuliah Daring. Child Education Journal. 2(1). 7 - 11

Zainal.,A. 2020. Pembelajaran Online Berbasis Proyek Salah satu Solusi Kegiatan Belajar Mengajar di Tengah Pandemi Covid-19. Jurnal Ilmiah Profesi Pendidikan. 5(1). 38 44 